\title{
Bioactive components from Ficus glomerata
}

\author{
N. N. Rahman, M. Khan, and R. Hasan \\ Department of Pharmacy, Dhaka University, Dhaka 1000, Bangladesh.
}

\begin{abstract}
Different parts of the plant Ficus glomerata Roxob was extracted with water and organic solvents. The effects of these extracts on blood sugar level of streptozotocin induced diabetic rats were studied. The pet ether extract of the stem bark of the plant reduced the blood sugar level significantly. Extracts from fruit and latex of the plant did not have any significant effect on blood sugar level of these diabetic rats. The pet ether extract of the stem bark completely inhibited the enzymes glucose-6-phosphatase and arginase and activated the enzyme glucose-6-phosphate dehydrogenase from rat liver. Extracts from fruit and latex inhibited only glucose-6-phosphatase but not arginase from rat liver. A number of components from pet ether extract of the stem bark were isolated and purified. The effect of these purified components on pure enzyme glucose-6-phosphate dehydrogenase were investigated. The chemical characterisation of some of these components were carried out.
\end{abstract}

\section{Introduction}

A large number of plants belonging to different families posses hypoglycemic activity. Hypoglycemic activity of Momordica charantia or karella (Cucurbitacea) has been reported by Ram(1) in 1950. Mirakami and co-workers in 1985 reported the isolation of hypoglycemic agents from Panax jinseng roots(2). Medicinal values of different parts of the plant Ficus glomerata Roxob (Moraceae) have been reported in various literatures(3-5). Baslas and Agha(6) in (1988) reported that a component B-sitosterol-D-glucoside from the stem bark of F. glomerata posseses hypoglycemic property(6).

In diabetes, activity of some enzymes such as glucose-6-phosphatase,fructose 1,6diphosphatase and arginase increases in the liver(7-9). Besides, activity of the enzymes like phosphofructo kinase and glucose-6-phosphate dehydrogenase decreases in the liver $(10,11)$. This project was undertaken to investigate the mechanism of hypoglycemic action of various plant parts of $F$. glomerata Roxob. The in vitro effect of the hypoglycemic principle on enzymes such as glucose-6-phosphatase, glucose-6-phosphate dehydrogenase and arginase has been investigated. Some of the active principles were isolated, purified and their action on pure enzyme glucose-6-phosphate dehydrogenase were carried out.

\section{Methods and Materials}

Three parts of the plant $F$. glomerata Roxob, stem bark, fruits and latex were sun dried powdered and were extracted with petroleum ether $60-80^{\circ}$. The extracts were dried under vacuum. Forty eight long Evans male rats weighing between $200-250 \mathrm{~g}$ and aged 100-150 days were used in the experiments. The rats were divided into four groups. Two groups were made diabetic while two other groups were kept normal. Diabetes was introduced by streptozotocin treatment. Blood glucose level was estimated by Nelson-somogy $\operatorname{method}(12,13)$. The extract $1 \mathrm{~g}$ was mixed with normal diet and fed to the rats for 10 days. The control group of rats were given normal diet without the plant extract. Blood was collected by 
tail puncturing after 5,7 and 10 days of feeding. Activity of glucose-6-phosphatase was determined according to the method of Biginske and co-workers(14), glucose-6-phosphate dehydrogenase was assayed according to the method of Waller and Lohar(15) and arginase activity was measured following the method of Roman and Ruys(16). Four components were separated from the pet ether extract of the stem bark of F.glomerata by vacuum chromatography followed by thin layer chromatography some physicochemical tests were performed to characterise the compounds. The effect of these compounds on the pure enzyme glucose-6phosphate dehydrogenase was determined.

\section{Results}

The pet ether extract of stem bark, fruits and latex were administered orally to three sets of rats, each set comprises of a group of diabetic and a group of normal rats and the blood sugar level was estimated after 5, 7 and 10 days. The results are represented in Fig. 1. It has been found that the blood sugar level in the normal rats was lowered by $16 \%$ and in diabetic rats was $62 \%$ after the administration of the stem bark extract Fig. $1 \mathrm{a}$. The blood sugar level was lowered by $11 \%$ in normal rats and by $20 \%$ in diabetic rats after 10 days of administration of fruit extract Fig. $1 \mathrm{~b}$. The pet ether extract of the latex of the plant had no significant effect on the blood sugar level of diabetic rats Fig.1c. The lowering in blood sugar level in normal as well as diabetic rats were to the extant of $7 \%$ and $8 \%$ respectively. These results indicate that most of the hypoglycemic principles are present in the stem bark of the plant.

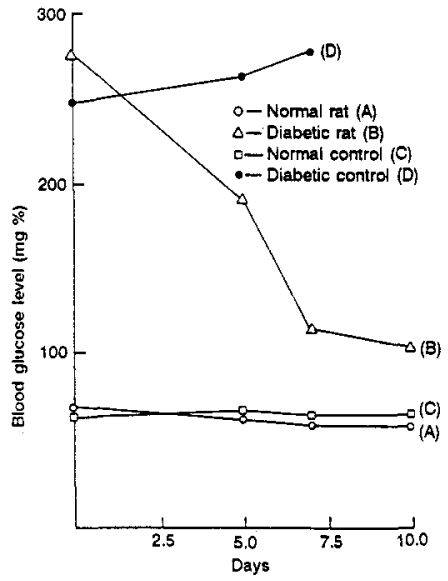

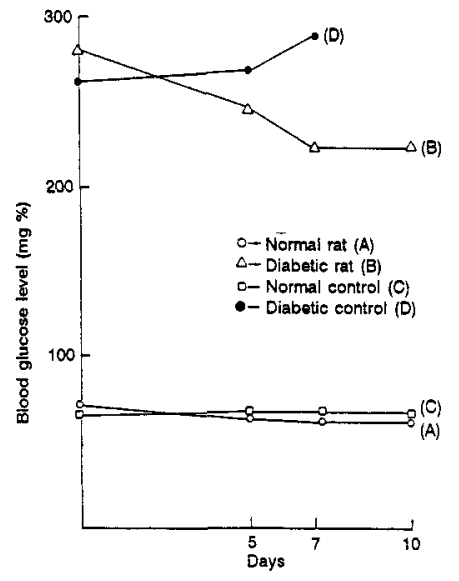

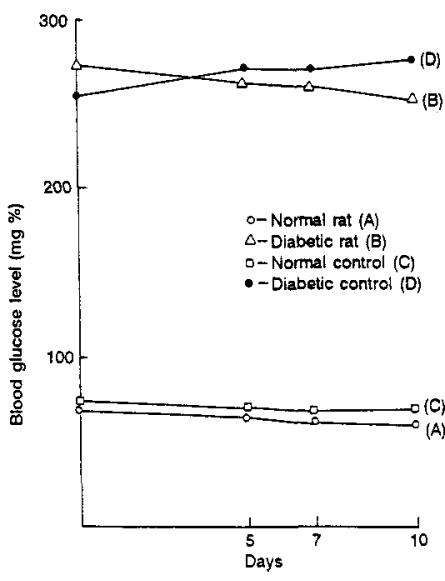

Fig.1 Effect of pet ether extract from stem bark (a), fruits (b), and latex (c) of $F$. glomerata Roxob on blood glucose level of different rats.

(A) Blood sugar level of normal rats after treatment with pet ether extract, (B) Blood sugar level of diabetic rats after treatment with pet ether extract, $(C)$ Blood sugar level of normal rats, (D) Blood sugar level of diabetic rats.

The pet ether extract of stem bark was tested on three enzymes glucose-6-phosphatase, glucose6-phosphate dehyogenase and arginase. The rat liver homogenate was centrifuged at $9000 \mathrm{rpm}$ and supernatant was used for enzyme assay. The pet ether extract was dried and suspended in imidazole buffer. A good suspension was made by sonication. The suspension at a concentration of $0.1 \%$ to $0.8 \%$ was added to a final volume of $2.5 \mathrm{ml}$ reaction mixture containing the enzyme and the substrate. The reaction was stopped after 15 minuets by adding $3 \%$ TCA solution. The amount of inorganic phosphate liberated by glucose-6-phosphatase was determined. The result is presented in Fig.2a. and it was found that $0.6 \%$ suspension of the pet ether extract of $F$. glomerata Roxob stem bark completely inhibited the enzyme glucose-6phosphatase. The fruits and latex extract inhibited this enzyme to the extent of $40 \%$ and $15 \%$ respectively. Glucose-6-phosphate dehydrogenase was activated by the pet ether extract of the stem bark of $F$ glomerata. The suspension of pet ether extract at a concentration of $0.1 \%$ to $0.8 \%$ was added to the enzyme assay mixture having $2.5 \mathrm{ml}$ of final volume. The enzyme activity increases linearly with the addition of higher concentration of the pet ether extract of stem bark and levelled off when the concentration of the extract was raised to $0.7 \%$ Fig. $2 \mathrm{~b}$. This indicates that the pet ether extract from the stem bark of the plant activate the enzyme significantly. The 
fruit and latex extracts do not have any significant effect on this enzyme. Arginase was strongly inhibited by the same concentration of the stem bark extract Fig.2c.
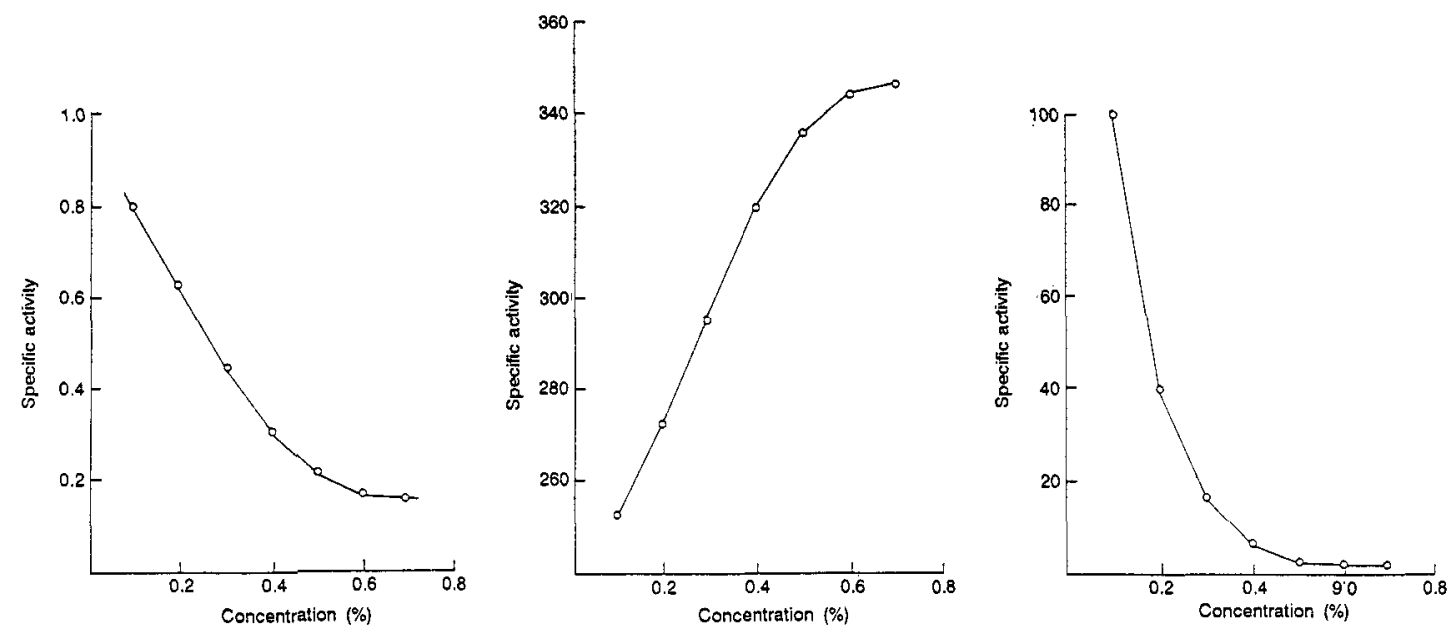

a

$b$

$c$

Fig.2 In vitro effect of pet ether extract of stem bark of Ficus glomerata Roxob on glucose-6. phosphase, (a) glucose-6-phosphate dehydrogenase (b), and on arginase (c), from rat liver.

The $K_{m}$ and $V_{\max }$ of glucose-6-phosphatase was determined using different concentration of the stem bark extract Fig.3. The result indicates that the enzyme is competitively inhibited by the pet ether extract of the stem bark.

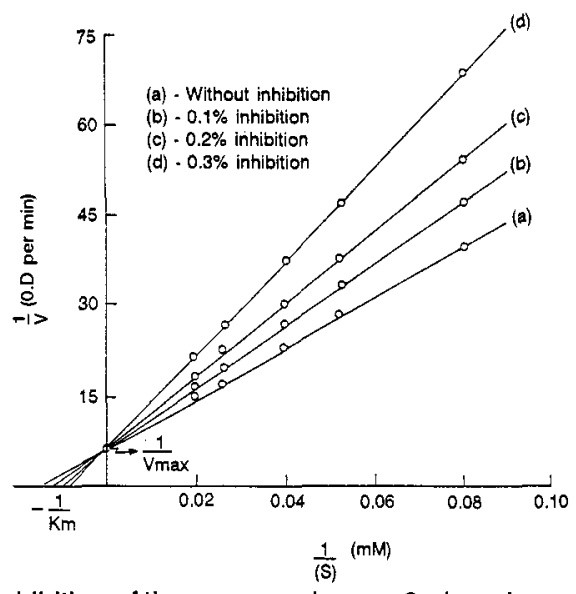

Fig. 3 Competitive inhibition of the enzyme glucose-6-phosphase from rat liver by the pet ether extract of stem bark of $F$. glomerata Roxob.

Four components were separated from the pet ether extract of the stem bark of $F$ glomerate by vacuum liquid chromatography. The structure of some of these components were determined. These components were found to activate pure enzyme glucose-6-phosphate dehydrogenase Table 1. An alkaloid has been isolated from the dried water extract of the stem bark(17). The compound has got antibacterial activity(18).

TABLE 1. Effect of the isolated components on glucose-6-phosphate dehydrogenase.

\begin{tabular}{lcc}
\hline Compound & Enzyme activity (unit/min) & Increase of activity (fold) \\
\hline Enzyme + G-6-PO & & - \\
$\mathrm{PE}$ (B-sitosterol) & 187.60 & 1.46 \\
$\mathrm{PE}-1$ (B-amyrin) & 273.20 & 1.13 \\
$\mathrm{PE}-2$ & 212.00 & 1.44 \\
$\mathrm{PE}-3$ (lupiol acetate) & 270.25 & 1.27
\end{tabular}




\section{Discussion}

The hypoglycemic active principle is largely present in the stem bark of F.glomerata Roxob. Other parts such as fruits and latex show poor hypoglycemic activity. This finding is in good agreement consistent with the work of Basal and Agha(6).

The hypoglycemic principles from the stem bark inhibit the enzyme glucose-6-phosphatase and arginase. The former enzyme is involved in dephosphorylation of glucose while the later is involved in the synthesis of urea. Phosphorylation of glucose to glucose-6-phosphate is an obligatory step in the metabolism of glucose. Glucose-6-phosphatase action helps in raising the blood glucose level. In vivo inhibition of glucose-6-phosphatase would amounts to lowering of blood glucose level. Glucose-6-phosphate dehydogenase is involved in the oxidation of glucose through hexose monophos-phate pathway. Activation of this enzyme is therefore involved in the utilisation of glucose with the concomitant production of NADPH which is involved in the synthesis of fatty acids. Arginase inhibition may affect gluconeogensis and urea synthesis. Therefore, the in vitro inhibition and activation of these enzymes in presence of extracts from different parts of F.glomerata may be correlated with their hypoglycemic activity. We have not yet ascertained whether the inhibitors of the two enzymes glucose-6-phosphatase and arginase are identical molecules.

The four components purified from the pet ether extract of the stem bark of F.glomerata Roxob have got activation effect on the pure enzyme glucose-6-phosphate dehydrogenase at a different intensity Table 1 . Total structure of the two components were determined. They are $\beta$-sitosterol and $\beta$-amyrin. $\beta$-sitosterol inhibited glucose-6-phosphate dehydrogenase at a higher rate than the other compounds.

\section{Acknowledgement}

The authors are thankful to Dr. A. Rashid, department of Pharmacy and Dr. A. U. Ahmed, department of Biochemistry, Dhaka University for their help during the process. The authors are also thankful to Mr Khundkar Mahbub Zaman and Mr Jamilul Ishfaque of Advanced Chemical Industries Limited, Dhaka for their technical cooperation.

\section{References}

1. Ram,S, J. Ind.Med. Assoc 19,181(1950).

2. Murakami, Miki, Oshima, Yoshitero, Hikiono and Hiroshi,, J. Ethanopharmacol. 14(1), 69(1985).

3. Tscheche, R., Pharmacognosy and Phytochemistry Eds. Wagner, H. and Horhamme, L., Springier and Verlag Berlin p274-81(1971).

4. Kirtikar, K., and Basu L.M., Indian Medicinal plants Vol.3. published by Lalit M. and Basu, Allahabad, India. P. 169(1980).

5. Singhal, R.K.Herba Hung. 19(2), 17(1980).

6. Baslas, R. and Agha, K., Chem. Pharm. Bull. 2(1), 13(1988).

7. Webber, G., Lea, M.A., Fisher, E.A. and Stamm, N.B., Enzyme Biol. Clin.7, 11(1966),

8. Henri, G.H and Emile, V.S. Biochem. J. 206, 1(1982).

9. Shimke, R.T.,J Biol. Chem.237, 459(1962).

10. Emile, V.S. and Henri, G.H., Bichim, Biophys. Res. Commun, 101(3), 1085(1981).

11. Pitol, H.C., Ann, Rev, Biochem. 35,335(1966).

12. Nelson, N.A., J. Biol, Chem 153 337(1944).

13. Somogyi, M., J. Biol Chem. 160,61(1945).

14. Biginski, E.S and Zak, B., Clin. Chem. Acta. 5,834(1960).

15. Walter, H.D Lohar, G.W.and Tabatabari M., Klin, Wecher, 1022(1957).

16. Roman, W. and Ruys, J., Clin Enz, 2,121(1969).

17. Hasan, Q., Jalil, R., Hasan, C.M. and Rahman, N.N, Dhaka univ. J.Biol Sci 1, 7(1992).

18. Hasan, Q., Jalil R., Hasan, C.M. and Rahman N.N., Bang. pharma J.10(1), 9(1991). 